Thus, the conclusion is reached that injunctive relief should be generally available under Section 301, notwithstanding the express provisions of a statute enacted in another era for a different purpose. Such a rule encourages the confinement of economic warfare in labor-management relations to disputes which arise in the course of bargaining, leaving the recurrent problems which arise under the terms of existing contracts to more orderly processes of settlement.

\title{
LESSOR'S SECURITY ARRANGEMENTS AND THE INTERNAL REVENUE CODE
}

One increasingly popular form of landlord protection against defaulting tenants who leave lessors with vacant premises and perhaps falling rentals is the requirement of a substantial deposit upon the execution of the lease. ${ }^{1}$ These deposits are characterized as advance rent or bonuses, in which case the sum may be retained upon default or expiration of the lease, ${ }^{2}$ or as security deposits, the lessors contracting to return that portion not actually needed to pay for defaults. ${ }^{3}$ While a lessor will get the same economic rental benefits from either arrangement, ${ }^{4}$ its characterization has important tax consequences.

1 This procedure has definite advantages over other methods intended to provide security from the commencement of the lease. While a mortgage on other real estate can perhaps be obtained, there are the difficulties of prior claims, recording problems, and the need for some kind of foreclosure before the security can be realized. A surety adds another party to the lease and renders compromises more difficult; a professional surety adds the additional cost of premiums to the tenant's financial load. See Wilson, Lease Security Deposits, 34 Col. L. Rev. 426 (1934).

2 Advance rent: E.g., Galbraith v. Wood, 124 Minn. 210, 144 N.W. 945 (1914) and cases cited in I American Law of Property $\$ 3.73 \mathrm{n} .18$ (1952). The rule allowing the lessor to retain advance rent applicable to a remote future date was criticised in Lessee's Recovery of an Advance Payment of Rent, 25 Ill. L. Rev. 716 (1931).

Bonuses: Wm. Filene's Sons Co. v. Weed, 245 U.S. 597 (1918); In re Sun Drug Co., 4 F.2d 843 (C.A. 9th, 1925); A-1 Garage v. Lange Investment Co., 6 Cal.App.2d 593, 44 P.2d 681 (1935), cert. denied 296 U.S. 642 (1935). There may, however, be a rebate provision. E.g., Wood v. Hepwell, 107 Cal.App. 690, 290 Pac. 1040 (1930). See Methods of Securing Lessor against Rental Defaults on Long Term Leases, 45 Yale L. J. 537 (1936).

${ }^{3}$ See cases on security deposits in Provision in Lease for Pecuniary Forfeiture Where Lease Is Prematurely Terminated, 106 A.L.R. 292 (1937). Occasionally advance rent will be considered a security deposit if its amount is disproportionate to the damages suffered by the lessor. Jensen v. Sparkes, 53 F.2d 433 (C.A. 9th, 1931); Rez v. Summers, 34 Cal.App. 527, 168 Pac. 156 (1917).

${ }^{4}$ Assuming a ten year lease with an annual rent of $\$ 10,000$, the rational landlord will accept $\$ 10,000$ advance rent which he can invest for nine years, or a $\$ 10,000$ security deposit which he can also invest for nine years (assuming the security deposit is returned after the final rental payment is made, at the beginning of the tenth year). If he accepts a bonus he will expect an amount equal to the present value of receiving for nine years an interest annuity equivalent to the interest annuity that can be obtained by investing the advance rent or security deposit, plus an additional amount to compensate him for having a smaller sum to apply in case of breach. 
Advance rent and bonuses are taxed in the year of receipt. 5 This is so even though it is agreed that the advance rent will be refunded under certain conditions $^{6}$ or will in addition secure performance of the lessee's covenants. ${ }^{7}$ On the other hand, if the sum is successfully designated a security deposit, it is taxable only upon termination of the obligation to repay. ${ }^{8}$ This tax advantage results from the "claim of right" doctrine -it is not known that the deposit will ever become income in light of the obligation to return it upon expiration of the lease without default.

However, characterization of the initial sum is not always easy. In Clinton Hotel Realty Corp. v. Commissioner, ${ }^{10}$ a $\$ 21,000$ payment was credited in the lease as prepaid rent but was also labeled "security." The court held the payment to be a security deposit on the basis of the annual interest to be paid the lessee.11 In Gilken Corp. v. Commissioner ${ }^{12}$ the hybrid deposit was security for the lessee's performance, a credit toward the purchase price if the lessee exercised his option, and to be applied as rent in the final period only if not used for the other purposes. But because the lessor was not required to

- Adcance rent: Hyde Park Realty, Inc. v. Comm'r, 211 F.2d 462 (C.A. 2d, 1954); Hirsch Improvement ᄂo. v. Comm'r, 143 F.2d 912 (C.A. 2d, 1944), cert. denied 323 U.S. 750 (1944). See Gilken Corp. v. Comm'r, 176 F.2d 141 (C.A. 6th, 1949); Astor Holding Co. v. Comm'r, 135 F.2d 47, (C.A. 5th, 1943); Commissioner v. Lyon, 97 F.2d 70 (C.A. 9th, 1938); Renwick v. United States, 87 F.2d 123 (C.A. 7th, 1936); H \& G Amusement Co., 46 B.T.A. 1095 (1942).

Bonuses: O'Day Investment Co., 13 B.T.A. 1230 (1928).

- South Dade Farms v. Comm'r, 138 F.2d 818 (C.A. 5th, 1943) (advance rent customarily refunded to prospective tenants unable to occupy premises).

7 Gilken Corp. v. Comm'r, 176 F.2d 141 (C.A. 6th, 1949).

${ }^{8}$ Warren Service Corp. v. Comm'r, 110 F.2d 723 (c.A. 2d, 1940); John Mantell 17 T.C. 1143 (1952); Estate of George Barker, 13 B.T.A. 562 (1928). Compare payments which may be credited toward the purchase price and are treated in the lease as consideration for an option. These are held not taxable when received because it is not known whether they represent income or a return of capital until it is clear that the option will or will not be exercised. C. V. L. Corp., 17 T.C. 812 (1951); Minneapolis Security Building Corp., 38 B.T.A. 1220 (1938). Where the lease involves an advance payment with provision tor later credit upon exercise of a purchase option but the payment is characterized in the lease as rent or a bonus, it has been held income to the lessor in the year of receipt. Gilken Corp. v. Comm'r, 176 F.2d 141 (C.A. 6th, 1949). This is so even though the purchase price first agreed upon was reduced in the lease, reflecting the payment. Estate of Mary G. Gordon, 17 T.C. 427 (1951), aff'd 201 F.2d 171 (C.A. 6th, 1952).

${ }^{9}$ Commissioner v. Lyon, 97 F.2d 70 (C.A. 9th, 1938). The doctrine was first enunciated in North American Oil Consolidated v. Burnet, 286 U.S. 417, 424 (1932): "If a taxpayer receives earnings under a claim of right and without restriction as to its disposition, he has received income which he is required to return, even though it may still be claimed that he is not entitled to retain the money, and even though he may still be adjudged liable to restore its equivalent."

10128 F.2d 968 (C.A. 5th, 1942).

"Although relying mainly on the interest payments, the court also considered other factors. While the amount paid was to be applied to the final year's rent, it also might have been applied in event of breach. Furthermore the deposit was to be returned in the event the building was destroyed. See In re Frey, 26 F.2d 472 (E.D. Pa., 1928).

12 176 F.2d 141 (C.A. 6th, 1949). 
segregate the sum or pay interest on it, ${ }^{13}$ the court held that it was taxable upon receipt as advance rent. This result was avoided through careful drafting in John Mantell. ${ }^{14}$ The lease provided that the deposit, security for the lessee's obligations including rent, was to be returned in the last year in installments equal to the rent installments two days after each rental payment. And although the sum was unrestricted and interest free, the Tax Court characterized it as a security deposit rather than advance rent. ${ }^{15}$ Similar results have been reached by two Courts of Appeals. ${ }^{16}$

Perhaps an explanation for the courts' generous treatment of landlords in these transactions can be found in the seeming injustice of immediately taxing advance rent. Although the Internal Revenue Code permits use of an accrual tax accounting method when it "clearly reflect[s] income,"17 the great majority of courts have not allowed the deferral of advanced receipts ${ }^{18}$ even though such deferral is an integral part of commercial accrual accounting. ${ }^{19}$ They have felt that such a result is prevented by the "claim of right" doctrine. ${ }^{20}$ But the prevention of such deferral means that the landlord's income

${ }^{13}$ Latitude in the lessor's use of the security deposit has never been questioned. Hyde Park Realty, Inc. v. Comm'r, 211 F.2d 462 (C.A. 2d, 1954); Hirsch Improvement Co. v. Comm'r, 143 F.2d 912 (C.A. 2d, 1944), cert. denied 323 U.S. 750 (1944). See Gilken Corp. v. Comm'r, 176 F.2d 141 (C.A. 6th, 1949); Astor Holding Co. v. Comm'r, 135 F.2d 47 (C.A. 5th, 1943); Commissioner v. Lyon, 97 F.2d 70 (C.A. 9th, 1938); Renwick v. United States, 87 F.2d 123 (C.A. 7 th, 1937).

1417 T.C. 1143 (1952).

${ }^{15}$ Cf. Jack August, 17 T.C. 1165 (1952), decided on the same day with an opinion by the same judge. In that case the original lease provided that the advance payment did not have to be returned and there was to be no rent the final year. After several months the first lease was superseded by one which described the initial payment as a security deposit, this time with an obligation to repay, and with rent to be due the final year. The court held that the lessor must pay tax on the advance payment; at the time it was received the parties intended it to be advance rent.

${ }^{16}$ Bradford Eotel Operating Co. v. Comm'r, 244 F.2d 876 (C.A. 1st, 1957); Warren Service Corp. v. Comm'r, 110 F.2d 723 (C.A. 2d, 1940).

17 Int. Rev. Code $\$ 446$ (b), 26 U.S.C.A. $\$ 446$ (1954).

18 E.g., Curtis R. Andrews, 23 T.C. 1026 (1955).

${ }^{19}$ Katz, Accounting 44 (1954).

${ }^{20}$ See note 9 supra. A mounting onslaught on this doctrine led to Section 452 of the 1954 Code, under which an accrual basis landlord might defer the payment of his tax on prepaid rent. This provision, however, was retroactively repealed in 1955 because of the adverse effect on government revenue during the transition period. 68A Stat. 152 (1954), repealed by 69 Stat. 134 (1955). The applicability of the claim of right cases to prepaid income was vigorously challenged in Beacon Publishing Co. v. Comm'r, 218 F.2d 697 (C.A. 10th, 1955) in which a deferred tax on prepaid magazine subscriptions was allowed. In reversing the decision of the Tax Court, Judge Pickett said, "[T]he tax court holds that advance payments received by a taxpayer, which are subject to income tax, must be returned in the year of receipt if owned or claimed by the taxpayer, regardless of the method of accounting which has been adopted, or when the funds are actually earned. Such application of the rule limits the accrual method to that class of cases where the money has been earned and the right to it has been fixed, but the receipt is delayed to a subsequent period." Id., at 700. This view also received strong support in Justice Harlan's dissent in Automobile Club of Michigan v. Comm'r., 353 U.S. 180, 190 (1957). 
is thereby distorted since the expenses of earning that income are deductible only in a later period. ${ }^{21}$ The courts' apparent willingness to characterize these deposits as security rather than rent may be an attempt to avoid the harsh results of the "claim of right" doctrine.

When the deposit is not classified as advance rent a further problem arises. Often the parties desire to terminate the lease before the expiration date, and as a result of their agreement the lessor keeps all or part of the security deposit. In this area there seems to be an overextension of the lenient attitude toward landlords. The two Courts of Appeals passing on the question have held that the lessor realized as taxable income only the present value of the cancelled future obligation to repay the deposit. ${ }^{22}$ They reasoned that since the lessors were to have free and unrestricted use of the deposit until a future date, on premature termination they were relieved only from their obligation to repay at that future time..$^{23}$ Consequently the releases were worth only the present value of that future income. The free use of the deposit was distinguished from the situation where the lessor is obligated to pay interest on the deposited sum: "In such a case the present worth of a release from an obligation to repay .... is presumably the face amount of the obligation; the value to the lessor of the money in the interim is offset by the obligation to pay interest during the period." 24

This reasoning appears to overlook the fact that presumably the parties had already discounted the deposit in the course of terminating the lease. Thus in Bradford Hotel Operating Co. v. Commissioner ${ }^{25}$ it seems reasonable to believe that the $\$ 185,000$ retained by the lessor represented the present value of receiving an interest annuity on the $\$ 250,000$ deposit until the

${ }^{21}$ The accrual of a deduction is permitted only where the obligation to pay was unconditionally fixed during the year of accrual. Brown v. Helvering, 291 U.S. 193 (1934). A deduction for estimated expenses accordingly is not usually allowed. See Amalgamated Housing Corp., 37 B.T.A. 817 (1938), aff'd 108 F.2d 1010 (C.A. 2d, 1940) (reserve out of rentals to cover cost of renovating apartment at end of tenant's occupancy held not deductible). But cf. Pacific Grape Products v. Comm'r, 219 F.2d 862 (C.A. 9th, 1955) (stressing that the expenses could be estimated accurately). Thus a lessor is taxed on the gross advance rent in the year of receipt, rather than on the profit he expects to make on the lease during the year to which the rent is applicable. Section 462 of the 1954 Code granted relief in this area but like Section 452 was retroactively repealed the following year. 69 Stat. 134 (1955).

22 Bradford Hotel Operating Co. v. Comm'r, 244 F.2d 876 (C.A. 1st, 1957), rev'g 26 T.C. 454 (1956); Warren Service Corp. v. Comm'r, 110 F.2d 723 (C.A. 2d, 1940), rev'g 39 B.T.A. 856 (1939). In the Bradford case the lease provided for a non-interest bearing security deposit of $\$ 250,000$ and an annual rental of the same amount; the lessor retained $\$ 185,000$ upon premature termination. In the Warren Service case the lease called for a non-interest bearing deposit of $\$ 125,000$, an annual rental of the same amount, and the lessor kept the entire sum upon termination.

23 "The value of a release of an obligation to pay $\$ 125,000$ in 1941, without interest, is obviously less than the value of the release of a debt for like amount presently due... 'Tt is self-evident that a given sum of money in hand is wor th more than a like sum of money payable in the future." "Warren Service Corp. v. Comm'r, 110 F.2d 723, 725 (C.A. 2d, 1940).

24 Ibid.

${ }^{25}$ See note 22 supra. 
original date of expiration. ${ }^{26}$ Since this annuity must have been planned as part of the rent, ${ }^{27}$ the $\$ 185,000$ must be a present settlement of future rent.

In Warren Service Corp. v. Commissioner ${ }^{28}$ the lessor retained the entire security deposit. This would seem to indicate that the present value of the interest annuity was not sufficient to compensate for falling rentals and whatever profit the lessor could derive from the termination. ${ }^{29}$

Thus it would appear that there is no difference between these releases and outright cash settlements of future rent obligations. And in Hort v. Commissioner $^{30}$ the Supreme Court said that the latter is taxable in full when received.

The amount received by petitioner must be included as gross income in its entirety. ... [The definition of income] would have included a prepayment of the discounted value of un-matured rental payments whether received at the inception of the lease or at any time therafter. ... [I]t is immaterial that petitioner chose to accept an amount less than the strict present value ... rather than to engage in litigation. ${ }^{31}$

But while the Warren and Bradford treatment of the landlord taxpayer is perhaps overly generous, present tax law makes the result of the above analysis perhaps overly strict. Since the amount retained by the lessor upon termination represents, at least in part, a supplement to the rent to be received from a future tenant, just tax accounting should allow either its deferral over the remainder of the terminated lease or else a reserve for future expenses. ${ }^{32}$ At first glance it might appear that the Warren and Bradford rule can be justified as a rough approximation of this result, but very often this irrational

${ }^{26}$ The security deposit was to have been repaid in 1982 . The lease was cancelled in 1950 . At a $4 \%$ interest rate the lessee received a sum $(\$ 65,000)$ approximating the present value of a right to receive $\$ 250,000$ in 1982 , while the lessor retained the present value $(\$ 185,000)$ of receiving an interest annuity for the 32 years. The dissenting judge in the Tax Court employed a similar approach. Bradford Hotel Operating Co., 26 T.C. 454, 463 n. 3 (1956). However, by mistakenly discounting the $\$ 185,000$ he in effect ended up with the present value of the present value of a 32 year annuity. His opinion was adopted on appeal by a majority of the Fourth Circuit.

27 See note 4 supra.

${ }^{28} 110$ F.2d 723 (C.A. 2d, 1940).

${ }^{29}$ This may be seen more clearly in the following hypothetical cases: Assume an annual rental of $\$ 1,000$ for ten years with free use of a $\$ 1,000$ security deposit. The real rental is $\$ 1,000$ plus say $\$ 50$ which the landlord can earn by investing the deposit at an arbitrary $5 \%$. If after one year the lease is terminated and the lessor can get a total of $\$ 1,000$ annually from a new tenant ( $\$ 950$ rent, $\$ 50$ interest on the deposit) he will then only bargain for the present value of the right to receive $\$ 50$ for nine more years, or approximately $\$ 355$ if the discount rate is $5 \%$. If a new tenant will pay only $\$ 950$ he will want twice $\$ 355$, and if $\$ 900$ then three times $\$ 355$. Under the last mentioned circumstances he presumably will retain the entire deposit, and perhaps will demand a further sum from the lessee.

${ }^{30} 313$ U.S. 28 (1940).

31 Id., at $30-31$.

${ }^{32}$ See text at note 21 supra. 
approach will achieve a tax saving grossly disproportionate to any savings achieved by deferral or reserves when the amount of the deposit retained is taxable in full. ${ }^{33}$

32 An illustration of this disproportion can be seen in the Bradford and the Warren cases themselves. In the former, the taxpayer reported as income only approximately $\$ 53,000$ of the $\$ 185,000$ it received. In the latter, where the lease had a shorter period to run, the taxpayer reported $\$ 85,000$ out of $\$ 125,000$. It would seem highly improbable that this saving would be offset by the taxpayer's gaining interest on deferred taxes, by his possible placement in a lower tax bracket, and by possible loss of any deduction for expenses not accrued if in the future year he should have no income.

\section{"ORDINARY AND NECESSARY AND LEGAI EXPENSES"}

\section{THE FEDERAL TAX AND STATE CRIMINAL LAW}

I

The Internal Revenue Code provides that the "ordinary and necessary expenses" of a trade or business may be deducted from gross income. ${ }^{1} \mathrm{Al}-$ though this provision does not explicitly condition deductibility upon legality, the Tax Court and lower federal courts have over the years established special rules for expenditures illegal in themselves or incurred in connection with illegal activities. ${ }^{2}$

With only a few exceptions, ${ }^{3}$ the courts have disallowed deduction of penalties paid for violations of federal ${ }^{4}$ and state $^{5}$ statutes and municipal ordinances. ${ }^{6}$ Disallowance has been justified by some courts on the ground that it is never ordinary and necessary to violate the law. ${ }^{7}$ Other courts have

1 "There shall be allowed as a deduction all the ordinary and necessary expenses paid or incurred during the taxable year in carrying on any trade or business, including-(1) a reasonable allowance for salaries or other compensation for personal services actually rendered; . . . (3) rentals. ..." Int. Rev. Code $\$ 162(a), 26$ U.S.C.A. \$162(a) (1954), formerly $\$ 23(a)(1)$ (A) of the 1939 Code.

24 Mertens, The Law of Federal Income Taxation $\$ 25.131$ et seq. (1954). With respect to expenses incurred in connection with illegal activities, the problem of deductibility is raised by the rule that income from such activities is taxable. United States v. Sullivan, 274 U.S. 259 (1927). Contra: Commissioner v. Wilcox, 327 U.S. 404 (1946), limited to its facts in Rutkin v. United States, 343 U.S. 130 (1952).

${ }^{3}$ Most of the exceptions involve non-wilful violation of maximum-price laws; e.g., Jerry Rossman Corp. v. Comm'r, 175 F.2d 711 (C.A.2d, 1949).

4 E.g., Great Northern Ry. v. Comm'r, 40 F.2d 373 (C.A. 8th, 1930), cert. denied 282 U.S. 855 (1930); David R. Faulk, 26 T.C. 948 (1956); Joseph Saltzman, 21 T.C. 777 (1954).

${ }^{5}$ E.g., Commissioner v. Longhorn Portland Cement Co., 148 F.2d 276 (C.A.5th, 1945); Burroughs Building Material Co. v. Comm'r, 47 F.2d 178 (C.A.2d, 1931).

- Harry Wiedetz, 2 T.C. 1262 (1943).

7 E.g., Great Northern Ry. v. Comm'r, 40 F.2d 372 (C.A. 8th, 1930). 